\title{
Genomic Organization of Repetitive DNA Elements and Extensive Karyotype Diversity of Silurid Catfishes (Teleostei: Siluriformes): A Comparative Cytogenetic Approach
}

\author{
Sukhonthip Ditcharoen ${ }^{1}$, Luiz Antonio Carlos Bertollo ${ }^{2}$, Petr Ráb ${ }^{3}$, Eva Hnátková ${ }^{4}$, \\ Wagner Franco Molina ${ }^{5}$, Thomas Liehr ${ }^{6}$, Alongklod Tanomtong ${ }^{1}$, Costas Triantaphyllidis ${ }^{7}$, \\ Catherine Ozouf-Costaz ${ }^{8}$, Sampan Tongnunui ${ }^{9}$, Puan Pengseng ${ }^{10}$, Weerayuth Supiwong ${ }^{11}$, \\ Rouben Aroutiounian ${ }^{12}$ and Marcelo de Bello Cioffi ${ }^{2, *}$ \\ 1 Toxic Substances in Livestock and Aquatic Animals Research Group, Department of Biology, \\ Faculty of Science, Khon Kaen University, Muang, Khon Kaen 40002, Thailand \\ 2 Departamento de Genética e Evolução, Universidade Federal de São Carlos (UFSCar), Rodovia Washington \\ Luiz Km. 235, C.P. 676, São Carlos, SP 13565-905, Brazil \\ 3 Laboratory of Fish Genetics, Institute of Animal Physiology and Genetics, Czech Academy of Sciences, \\ Rumburská 89, Liběchov 277 21, Czech Republic \\ 4 Department of Zoology and Fisheries, Faculty of Agrobiology, Food and Natural Resources, \\ Czech University of Life Sciences, Kamýcká 129, Prague 165 00, Czech Republic \\ 5 Departamento de Biologia Celular e Genética, Centro de Biociências, Universidade Federal do Rio Grande \\ do Norte (UFRN), Natal, RN 59078970, Brazil \\ 6 Institute of Human Genetics, University Hospital Jena, Jena 07747, Germany \\ 7 Department of Genetics, Development and Molecular Biology, Faculty of Sciences, School of Biology, \\ Aristotle University of Thessaloniki, University Campus, Thessaloniki 54124, Greece \\ 8 Laboratorie Evolution Paris Seine, Institut de Biologie Paris Seine (IBPS), Sorbonne Universités, Case 5, \\ 7 Quai St Bernard, Paris, 75952 Paris CEDEX 05, France \\ 9 Department of Conservation Biology, Mahidol University, Kanchanaburi Campus, Sai Yok, \\ Kanchanaburi Province 71150, Thailand \\ 10 School of Agricultural of Technology, Walailak University, Thasala, Nakhon Si Thammarat 80160, Thailand \\ 11 Faculty of Applied Science and Engineering, Khon Kaen University, Nong Khai Campus, Muang, \\ Nong Khai 43000, Thailand \\ 12 Department of Genetics and Cytology, Yerevan State University, Yerevan 0025, Armenia \\ * Correspondence: mbcioffi@ufscar.br; Tel.: +55-016 3306-6885
}

Received: 8 June 2019; Accepted: 16 July 2019; Published: 19 July 2019

\begin{abstract}
The catfish family Siluridae contains 107 described species distributed in Asia, but with some distributed in Europe. In this study, karyotypes and other chromosomal characteristics of 15 species from eight genera were examined using conventional and molecular cytogenetic protocols. Our results showed the diploid number $(2 n)$ to be highly divergent among species, ranging from $2 n=40$ to 92 , with the modal frequency comprising 56 to 64 chromosomes. Accordingly, the ratio of uni- and bi-armed chromosomes is also highly variable, thus suggesting extensive chromosomal rearrangements. Only one chromosome pair bearing major rDNA sites occurs in most species, except for Wallago micropogon, Ompok siluroides, and Kryptoterus giminus with two; and Silurichthys phaiosoma with five such pairs. In contrast, chromosomes bearing $5 \mathrm{~S}$ rDNA sites range from one to as high as nine pairs among the species. Comparative genomic hybridization (CGH) experiments evidenced large genomic divergence, even between congeneric species. As a whole, we conclude that karyotype features and chromosomal diversity of the silurid catfishes are unusually extensive, but parallel some other catfish lineages and primary freshwater fish groups, thus making silurids an important model for investigating the evolutionary dynamics of fish chromosomes.
\end{abstract}


Keywords: fish cytotaxonomy; chromosome banding; FISH; rDNA classes; CGH

\section{Introduction}

The family Siluridae is a lineage of freshwater catfishes widely distributed through Eurasia, but with the highest diversity in South and Southeast Asia [1]. It comprises 107 recognized species [2], some of them also distributed in temperate regions, such as Silurus glanis, S. aristotelis, S. soldatovi, and S. asotus [3-7]. The phylogenetic position of this family remains not well resolved [8-13], although morphological and molecular data have confirmed its monophyletic status within Siluriformes $[3,8,9]$.

Siluridae catfishes represent one of the most interesting fish groups from a $2 n$ evolutionary point of view, owing to their wide distribution, unique ecological niche, and known evolutionary trajectory [7]. Siluridae includes one of the largest freshwater fish species-Silurus glanis-which commonly reaches $2 \mathrm{~m}$ in size and over $300 \mathrm{~kg}$ in weight [14], and is highly valued in the food market [15]. Several other species, such as Micronema cheveyi, Phalaconotus apogon, P. bleekeri, Wallago attu, and W. micropogon, also comprise important food sources [16] or are ornamental fishes, like the glass catfish Kryptopterus bicirrhis [17].

Cytogenetic studies have proven useful to discover and explore cryptic biodiversity in a number of fish groups [18]. Particularly, in complex and ecologically diverse fish groups, cytogenetic studies have made important contributions to elucidate the evolutionary pathways of distinct fish groups, owing to their particular chromosomal and genomic characteristics [19]. In fact, these approaches can reveal a set of characters usually not accessible by other research methods, thus refining evolutionary investigations $[19,20]$. Particularly, repetitive DNA sequences, which constitute the major component of the eukaryotic genome, have enormous potential for expanding the knowledge of karyotype differentiation [21]. In addition, the recent use of the comparative genomic hybridization (CGH) has allowed deeper analyses of fish genome organization at the chromosomal level by comparing closely related species [22-25].

Among the silurid catfishes, chromosomal studies are often restricted to conventional protocols to determine the diploid number $(2 n)$ and karyotype composition. Molecular cytogenetic approaches (e.g., chromosomal mapping of rDNA sequences) have been done in only two species of the genus Ompok [26]. Up to date, only 24 species from 8 of the 13 recognized genera had been cytogenetically examined (Table 1). The overall data show that the chromosome number varies from $2 n=28$ in Silurus microdorsalis [27] to $2 n=92$ in Kryptopterus cryptopterus [28].

Here, we add new chromosomal data for several silurid species from different genera, some of them analyzed for the first time, as well as others re-analyzed by different procedures (Table 1). We aimed to assess their karyotype structure, rDNA distribution, and interspecific genomic divergences through CGH experiments. The results added new informative characters useful in comparative genomics at the chromosomal level and highlighted extensive karyotype diversity among the analyzed species.

Table 1. Review of cytogenetic data in the family Siluridae. The species now analyzed are highlighted.

\begin{tabular}{|c|c|c|c|c|c|c|}
\hline Species & Locality & $2 n$ & NF & Karyotype & NORs/18S rDNA & Reference \\
\hline Belodontichthys truncatus & Thailand & 62 & 100 & $20 m+10 s m+8 s t+24 a$ & - & [29] \\
\hline B. truncatus & Thailand & 62 & 112 & $14 m+30 s m+6 a+12 t$ & 2 & [30] \\
\hline Kryptopterus bicirrhis & SE Asia & 60 & - & - & - & [31] \\
\hline K. bicirrhis & Thailand & 64 & 98 & $20 m+10 s m+4 s t+30 a$ & - & [29] \\
\hline K. bicirrhis & Thailand & 64 & 96 & $14 \mathrm{~m}+18 \mathrm{sm}+32 \mathrm{st} / \mathrm{a}$ & 2 & Present work \\
\hline K. limpok & Thailand & 60 & 86 & $12 \mathrm{~m}+14 \mathrm{sm}+34 \mathrm{st} / \mathrm{a}$ & 2 & Present work \\
\hline K. macrocephalus & Thailand & 62 & 98 & $24 m+12 s m+26 a$ & - & [32] \\
\hline K. macrocephalus & Thailand & 62 & 72 & $4 m+6 s m+52 s t / a$ & 2 & Present work \\
\hline Micronema cheveyi & Thailand & 78 & 96 & $4 m+6 s m+10 a+58 t$ & 2 & [30] \\
\hline
\end{tabular}


Table 1. Cont.

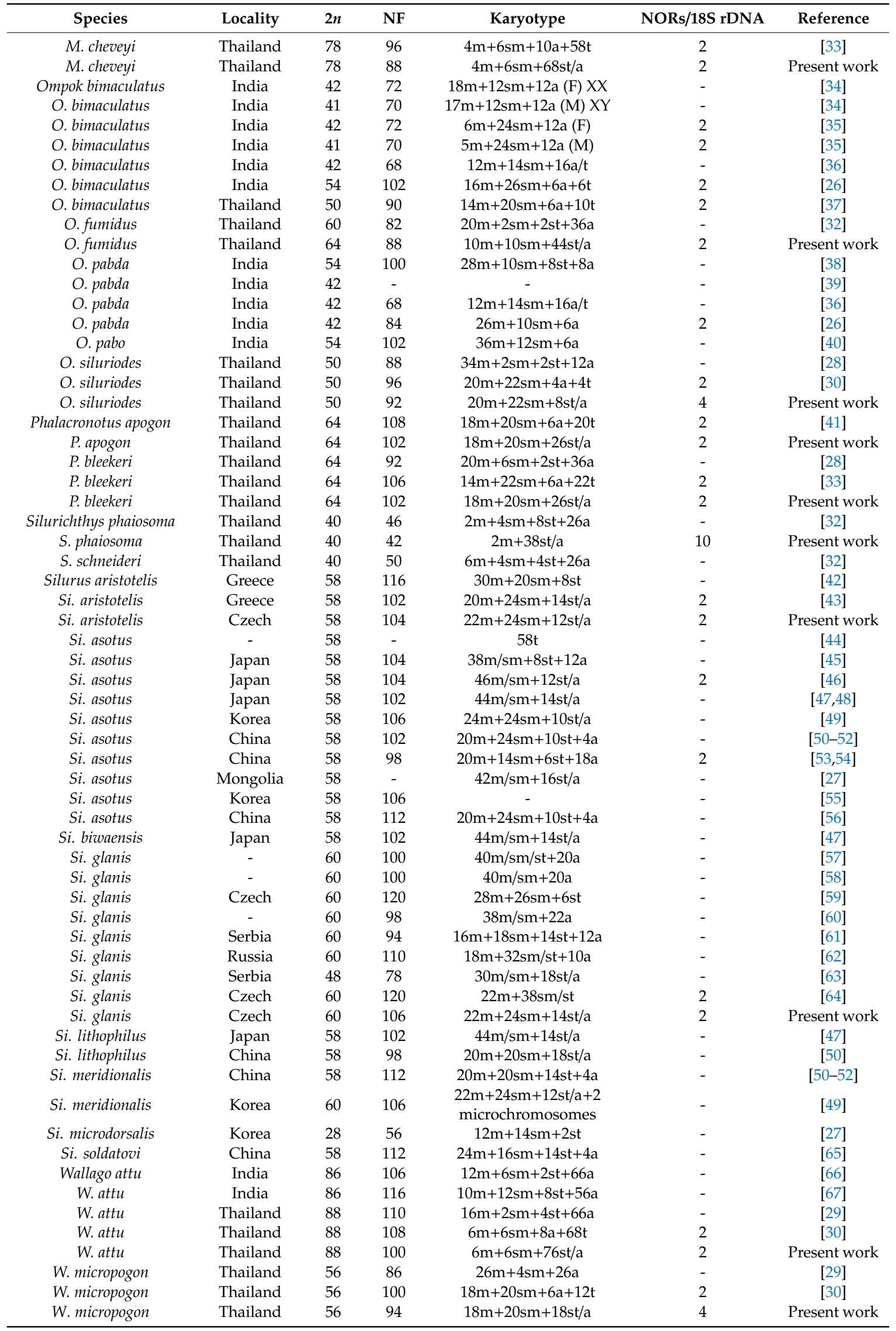

$\mathrm{NF}$ = fundamental number; $2 n$ = diploid number; $\mathrm{M}=$ male; $\mathrm{F}$ = female; and NOR = nucleolar organizer region. 


\section{Results}

\subsection{Standard Karyotypes}

The diploid number of the 15 species analyzed varied from 40 (Silurichthys phaiosoma) to 92 chromosomes (Kryptopterus giminus). Substantial $2 n$ variation occurs even among congeneric species. The only exception was observed for both Phalacronotus species, P. apogon, and P. bleekeri, which shared the same $2 n$ and karyotype structures (i.e., $2 n=64,9 m+10 s m+13 s t / a)$. In all species, no numerical or structural polymorphism between the sexes was observed, thus there was no evidence of differentiated sex chromosomes (Figures 1 and 2).

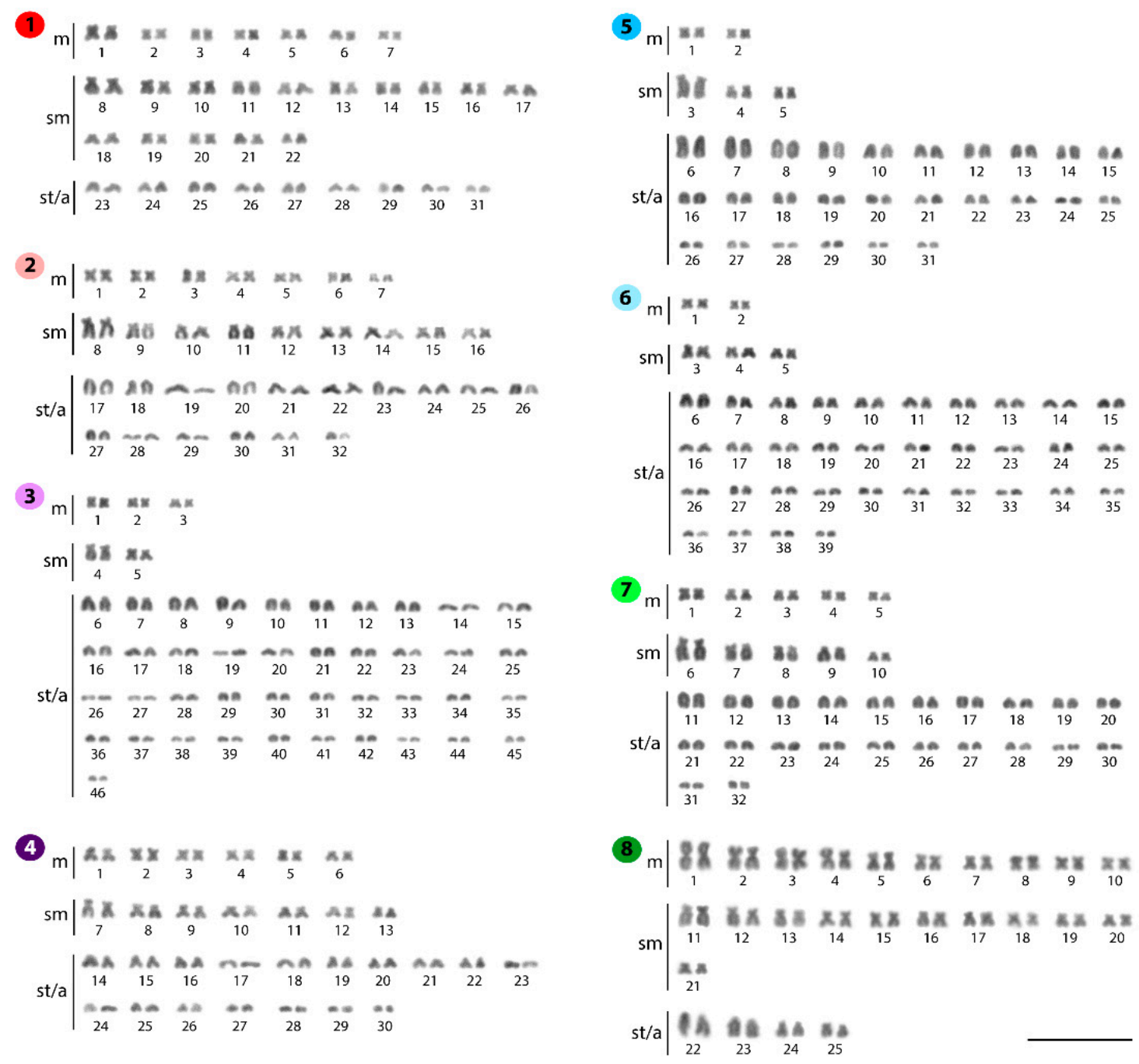

Figure 1. Karyotypes of Belodontichthys truncates (1); Kryptopterus bicirrhis (2); Kryptopterus geminus (3); Kryptopterus limpok (4); Kryptopterus macrocephalus (5); Micronema cheveyi (6); Ompok fumidus (7); and Ompok siluroides (8) arranged following Giemsa-staining. Bar $=5 \mu \mathrm{m}$. 

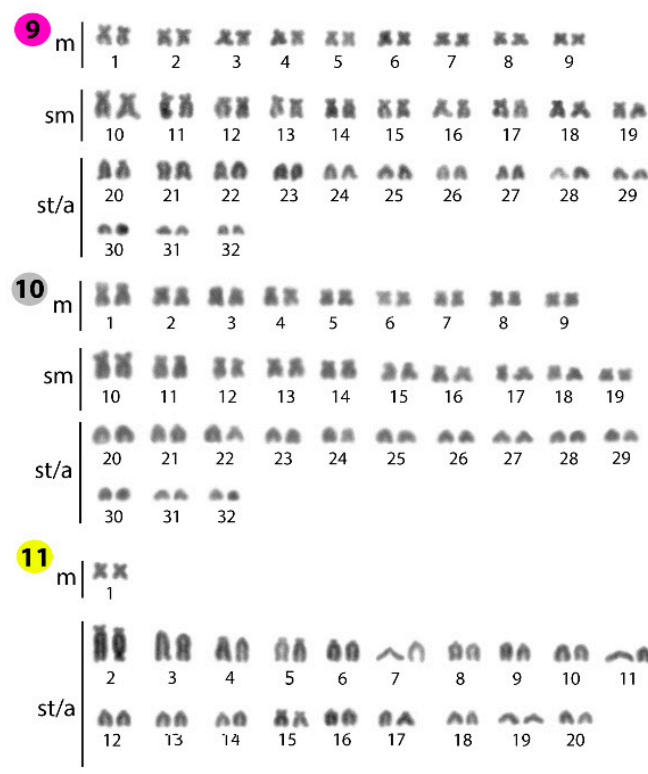

12

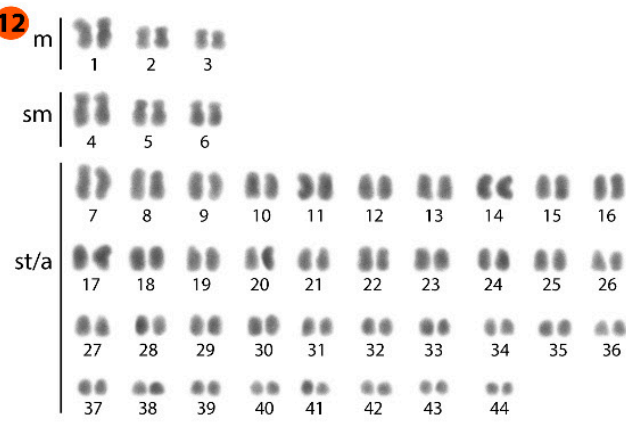

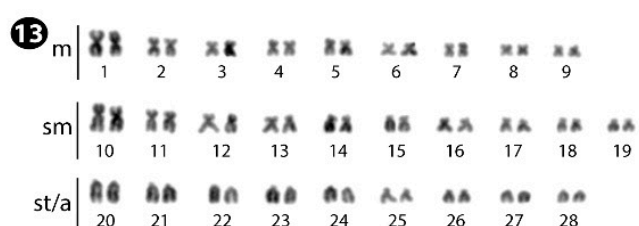

14

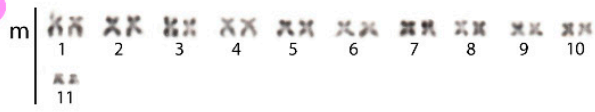

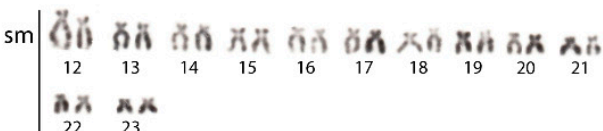

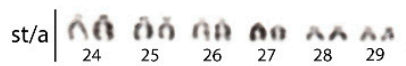

15

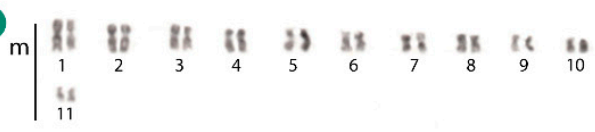

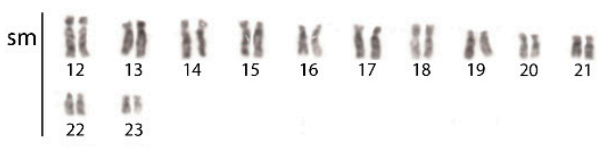

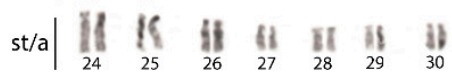

Figure 2. Karyotypes of Phalacronotus apogon (9); Phalacronotus bleekeri (10); Silurichthys phaiosoma (11); Wallago attu (12); Wallago micropogon (13); Silurus aristotelis (14); and Silurus glanis (15) arranged following Giemsa-staining. Bar $=5 \mu \mathrm{m}$.

\subsection{Fluorescence In Situ Hybridization (FISH)-Mapping}

The $18 \mathrm{~S}$ rDNA probe hybridized to only one chromosomal pair in most species, namely B. truncates, K. limpok, K. macrocephalus, M. cheveyi, O. fumidus, P. apogon, P. bleekeri, and W. attu. This site is located in the subtelomeric/telomeric region of the short arms of that chromosome pair in all species, except for K. bicirrhis, in which it is located in the telomeric region of the long arms. Exceptions for this frequent pattern are K. geminus, O. siluroides, and W. micropogon, in which two chromosome pairs bear $18 \mathrm{~S}$ rDNA genes and S. phaiosoma with five chromosome pairs (Figures 3-5).

In contrast, the $5 \mathrm{~S}$ rDNA sites showed a large variation in distribution, ranging from one chromosome pair in K. limpok, O. fumidus, O. siluroides, $W$. attu, and W. micropogon, up to six pairs in K. geminus, B. truncates, M. cheveyi, and S. phaiosoma. In addition, four other species had remarkably increased numbers of chromosomes displaying such sites, namely K. bicirrhis and K. macrocephalus with eight, and P. apogon and P. bleekeri with nine chromosome pairs (Figures 3-5). Fluorescence in situ hybridization (FISH) using the (TTAGGG) ${ }_{n}$ telomeric probe revealed hybridization signals on telomeres of all chromosomes of S. phaiosoma (Figure S1). 

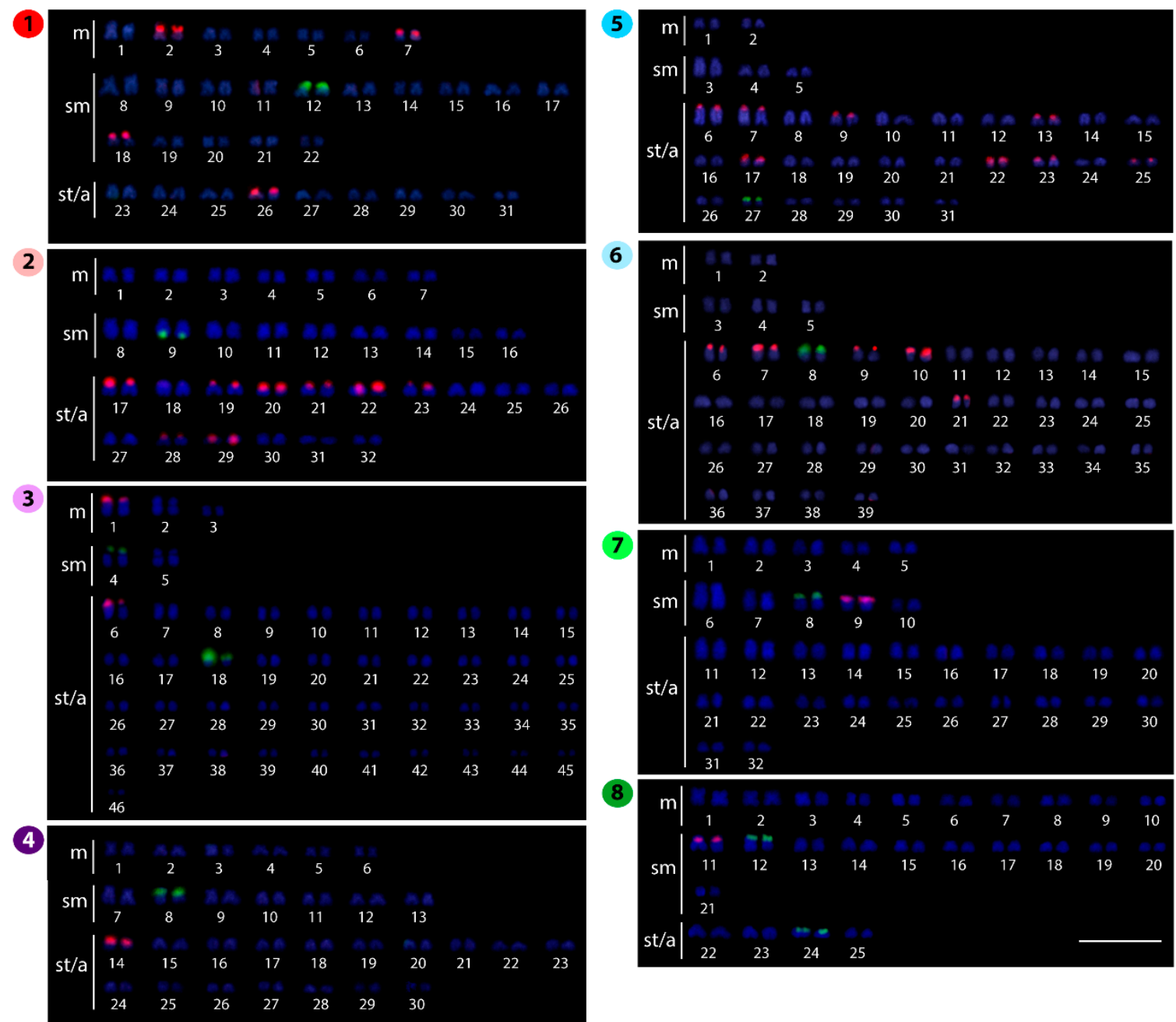

Figure 3. Karyotypes of Belodontichthys truncates (1); Kryptopterus bicirrhis (2); Kryptopterus geminus (3); Kryptopterus limpok (4); Kryptopterus macrocephalus (5); Micronema cheveyi (6); Ompok fumidus (7); and Ompok siluroides (8) arranged from chromosomes after double-fluorescence in situ hybridization (FISH) with $5 \mathrm{~S}$ rDNA (red) and $18 \mathrm{~S}$ rDNA (green) probes. Bar $=5 \mu \mathrm{m}$. 

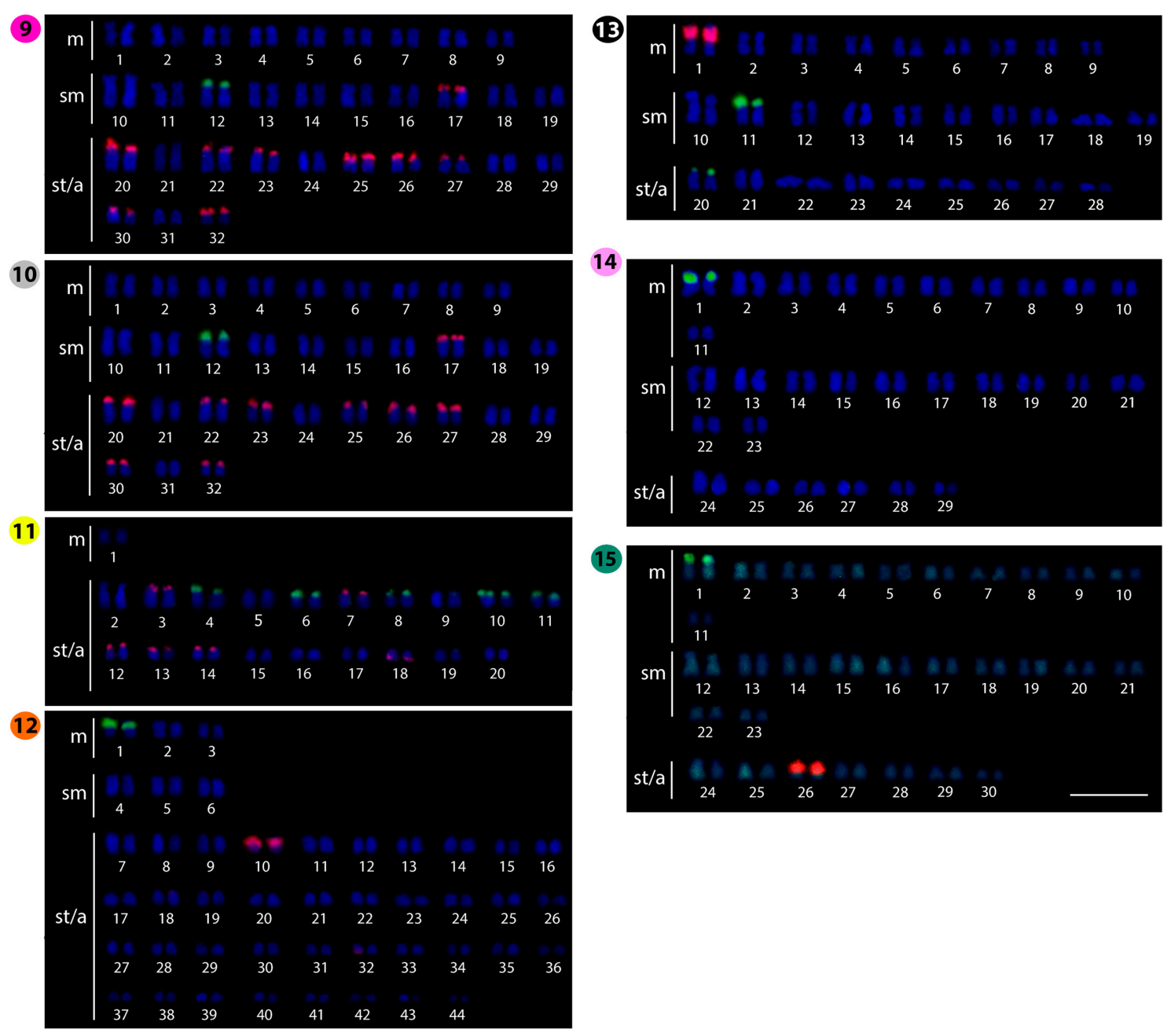

Figure 4. Karyotypes of Phalacronotus apogon (9); Phalacronotus bleekeri (10); Silurichthys phaiosoma (11); Wallago attu (12); Wallago micropogon (13); Silurus aristotelis (14); and Silurus glanis (15) arranged from chromosomes after double-FISH with 5S rDNA (red) and 18S rDNA (green) probes (except for S. aristotelis, where only $18 \mathrm{~S} \mathrm{rDNA}$ is indicated). Bar $=5 \mu \mathrm{m}$. 


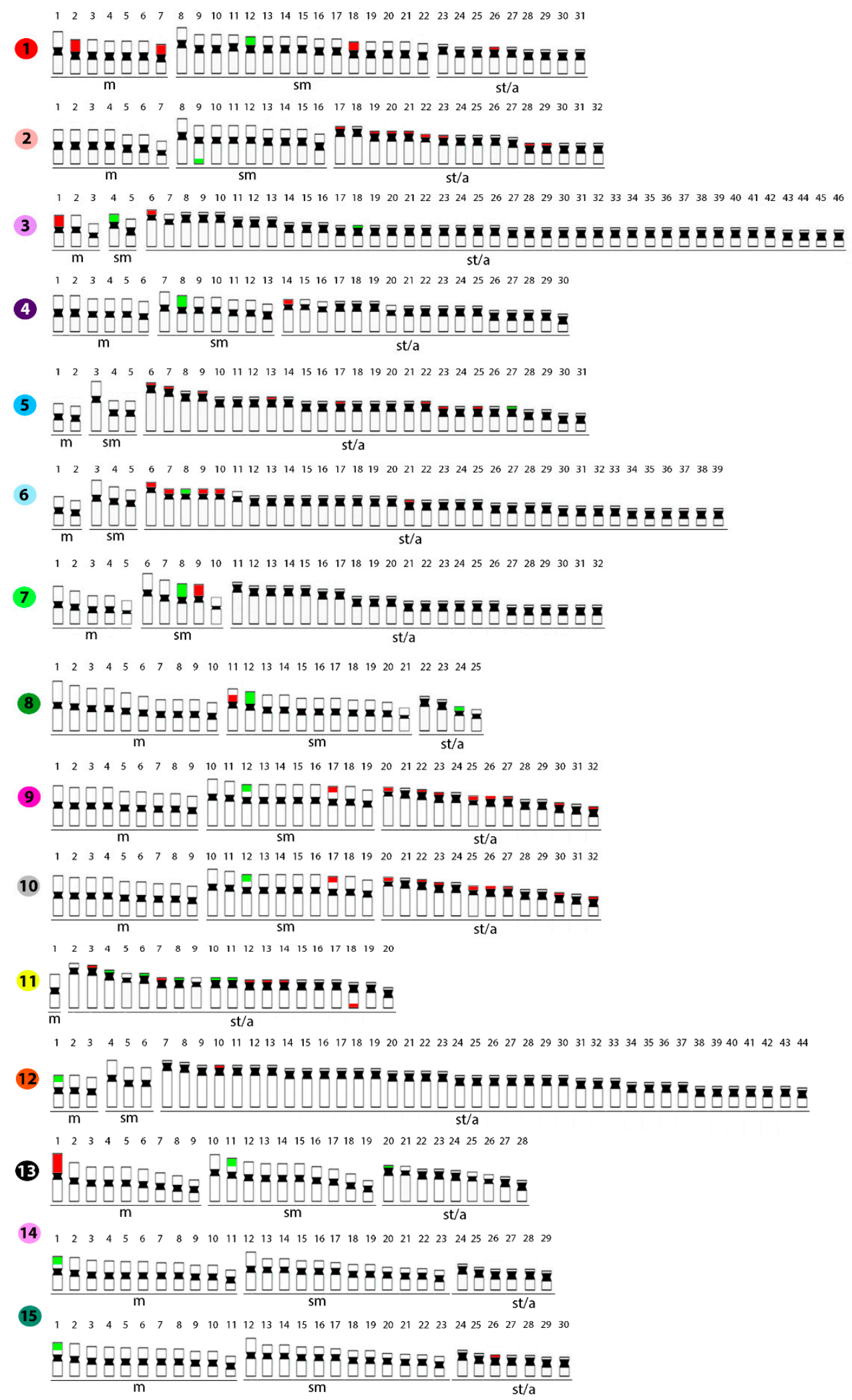

Figure 5. Representative idiograms of Belodontichthys truncates (1); Kryptopterus bicirrhis (2); Kryptopterus giminus (3); Kryptopterus limpok (4); Kryptopterus microcephalus (5); Micronema cheveyi (6); Ompok fumidus (7); Ompok siluroides (8); Phalacronotus apogon (9); Phalacronotus bleekeri (10); Silurichthys phaiosoma (11); Wallago attu (12); Wallago micropogon (13); Silurus aristotelis (14); and Silurus glanis (15), showing the distribution of the 5S (red) and 18S (green) rDNA sites on the respective chromosomes (except for S. aristotelis, where only $18 \mathrm{~S} \mathrm{rDNA}$ is indicated). 


\subsection{Comparative Genomic Hybridization (CGH)}

CGH experiments employing the gDNA of Kryptopterus (K. geminus $x$ K. limpok) and Wallago (W. attu $x W$. micropogon) indicated a large genomic divergence between the congeneric species. Specifically, K. geminus and W. attu exhibited many hybridization sites in the centromeric and terminal chromosomal regions when their own gDNA probes were hybridized against their chromosomal background. However, the K. limpok and W. micropogon gDNA probes produced only some weak terminal signals when hybridized against the K. geminus and W. attu chromosomes, respectively. In contrast, the Phalacronotus species (P. bleekeri and P. apogon) showed a significant shared repetitive content (Figure 6).

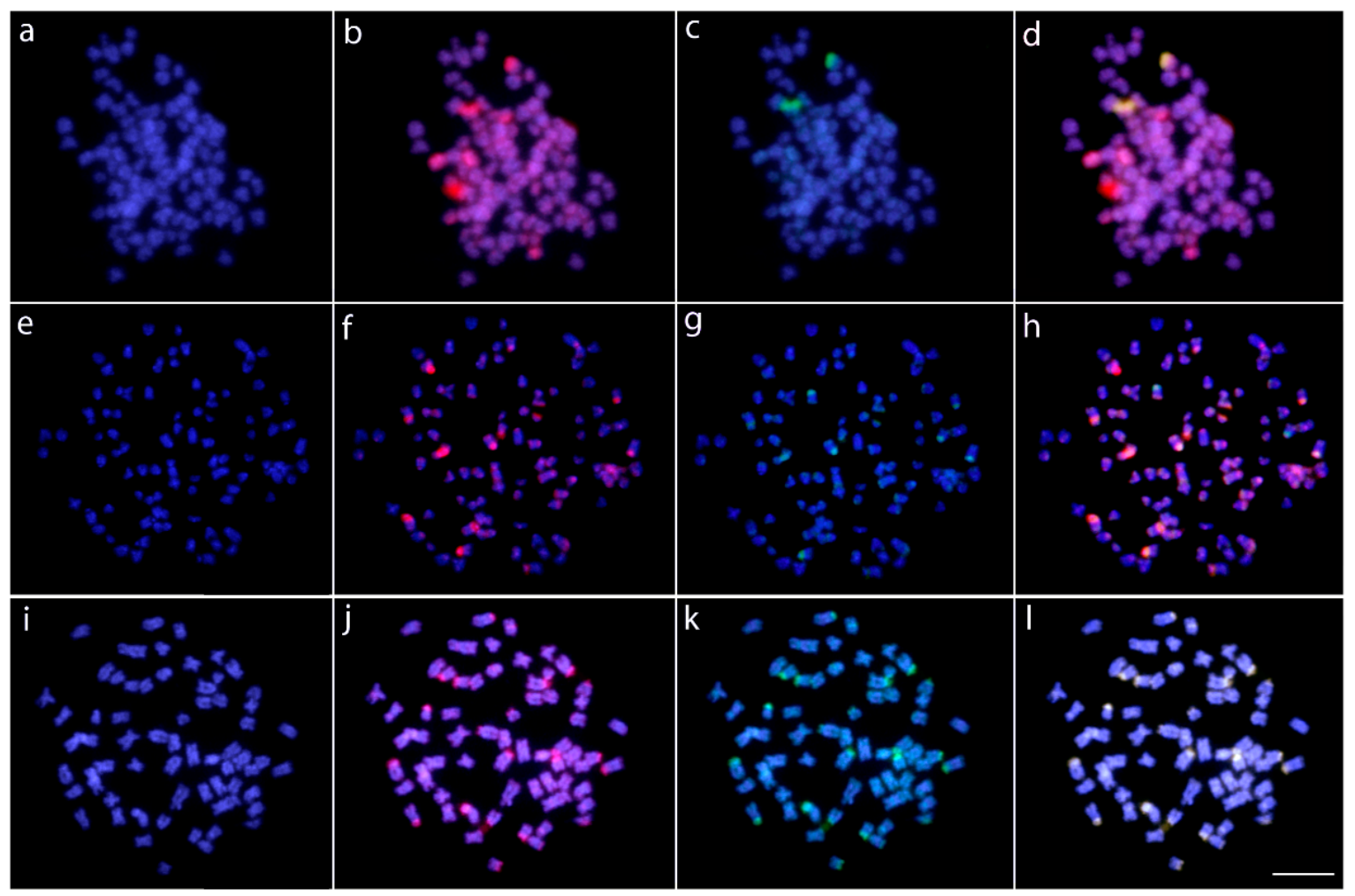

Figure 6. Metaphase chromosome spreads of Kryptopterus geminus (a-d), Wallago attu (e-h), and Phalacronotus bleekeri (i-1) after comparative genomic hybridization (CGH) procedures. Male-derived genomic probes from K. geminus and K. limpok were hybridized together against male chromosomes of K. geminus (a-d). Male-derived genomic probes from W. attu and W. micropogon were hybridized together against male chromosomes of W. attu (e-h). Male-derived genomic probes from P. bleekeri and P. apogon were hybridized together against male chromosomes of P. bleekeri (i-1). First column $(\mathbf{a}, \mathbf{e}, \mathbf{i})$ : DAPI images (blue). Second column $(\mathbf{b}, \mathbf{f}, \mathbf{j})$ : hybridization pattern using K. geminus (b), W. attu (f), and P. bleekeri (j) gDNA probes (red). Third column (c,g,k): hybridization pattern using $K$. limpok (c), W. micropogon (g), and P. apogon (k) gDNA probes (green). Fourth column (d,h,l): merged images of both genomic probes and DAPI staining. The shared genomic regions are depicted in yellow. Bar $=5 \mu \mathrm{m}$.

\section{Discussion}

The comparison of cytogenetic data for silurid species uncovered a large genomic diversification. This has been highlighted by some published data (Table 1), as well as here by highly diversified $2 n$, karyotype structures, numbers, and positions of ribosomal genes, and likely also by genomic differentiation, as preliminarily demonstrated by CGH experiments. The review of available cytotaxonomic data indicated a remarkable karyotype diversity, where the $2 n$ number ranges from 28 in S. microdorsalis to 92 in Kryptopterus cryptopterus and K. geminus (Table 1). Oliveira and Gosztonyi [68] 
suggested that $2 n=56$ corresponds to the typical number of chromosomes for Siluriformes, as this same number is found in Diplomystes, a sister group of all extant Siluriformes [69], in addition to $2 n=54-58$ being the most frequent pattern among siluriform catfishes. The extensive numerical variation of the chromosome number, both below and far above the supposedly basal $2 n$, as well as the rate of bi-armed chromosomes in the karyotypes, indicate that a diversified number of rearrangements including fissions, fusions, and inversions may have acted to give rise to karyotypic diversity noticed in this family.

What could have driven the extensive karyotype diversification among silurid species?

It is widely known that karyotype diversification relates to speciation processes [70-72], sometimes with repetitive DNAs acting as primary driving forces (reviewed in the work of [73]). The mapping of repetitive sequences, especially ribosomal genes, has proven useful for estimating evolutionary karyotype changes [74]. Although rDNAs represent conservative elements of the eukaryotic genomes, recent studies have shown that the dynamism of the rDNA clusters is strongly related to significant intragenomic diversification [21,75-81]. Accordingly, rDNA elements showed remarkable differences among silurid species, especially regarding the high variability in the number and position of the $5 \mathrm{~S}$ rDNA sites as compared with the more stable pattern of the $18 \mathrm{~S}$ rDNA sites.

Extensive chromosomal variability of $5 \mathrm{~S}$ rDNA loci also has been described for several other fish groups $([21,22,79,82]$; for review, see the work of [74]). A question that arises is whether the dispersion of this rDNA class would be a byproduct of genomic/chromosomal changes. However, the absence of a direct correlation between higher $2 n$ numbers and amplification and dispersion of the $5 S$ rDNA clusters is an indication that this rDNA class was not the unique trigger for the chromosomal rearrangements occurring among the respective silurid species. In this sense, an alternative and attractive hypothesis refers to the action of transposable elements. Indeed, in several species, a significant fraction of the rDNA units is interrupted by transposable elements (TEs) highly specialized for insertions [82-86]. In some cases, TEs have been postulated to play a decisive role in spreading rDNA sequences over the genome $[22,23,82]$. Remarkably, structural changes in the location of rDNAs also could be linked with speciation events. In the sister salmonid species, Coregonus albula and C. fontanae, ecological speciation was directly associated with the spreading of rDNA sites, affecting recombination rates in both genomes [22]. It is known that multiple rDNA insertions in new genomic regions may create "hot spots" that promote chromosome rearrangements, representing a pathway for rapid genome reorganization during speciation (reviewed in the work of [84]). Nevertheless, up to now, we have no data concerning TEs among silurid species, which will be the goal of further investigations to assess this hypothesis. Besides, it is known that a variety of teleost lineages have undergone one or more rounds of independent whole-genome duplications (WGDs), which are among the most important evolutionary events occurring in fish species [18]. Although there is no direct indicative that silurids analyzed here have experienced WDG events, we cannot exclude the potential role of this process in the high genomic/chromosomal divergence observed.

The available data for silurids allow us to recognize three particular patterns in relation to the $2 n$ numbers and karyotype structures that they present: (i) congeneric species that are highly divergent, as observed in Kryptopterus and Wallago species; (ii) congeneric species that share similar features, as represented by the two Phalacronotus species, P. apogon, and P. bleekeri; and (iii) particular species displaying a significantly lower chromosome number compared with the other species, as observed in S. phaiosoma. For the latter, although multiple chromosomal fusions would be expected to be related, no interstitial telomeric sequences (ITS) were observed (Figure S1). However, this does not definitely refute the possibility that fusion events occurred during karyotypic diversification, as losses of telomeric sequences can occur after such rearrangements, leading to gradual shortening of non-functional telomeric arrays [87-89].

Regarding the first two above-mentioned scenarios, we performed CGH experiments in order to assess whether they are linked with the repetitive DNA content. The remarkable chromosomal dynamism in both Kryptopterus and Wallago species corresponds with an extensive variation of their 
repetitive DNA content, as demonstrated by a range of non-overlapping species-specific signals revealing an advanced stage of sequence divergence among their genomes (Figure 7). In fact, such repetitive DNA differentiations occurred concomitantly with $2 n$ and structural changes in karyotypes. In contrast, no substantial variation of repetitive DNA content was found among the Phalacronotus species, where the hybridization of both gDNAs produced no species-specific signal amplifications (Figure 6). In these species, karyotypic changes were markedly reduced. As repetitive DNAs are highly abundant in eukaryotic genomes and display faster evolutionary rates $[19,90,91]$, their role as the main factor in promoting karyotype rearrangements has been extensively investigated. Several reports have evidenced huge inter-population variations of this genomic fraction, promoting biodiversity and possibly linked with ongoing speciation and differentiation of sex-specific regions [24,92-95].

Other siluriform groups also experienced massive karyotype differentiation. Clarias species (Clariidae), for example, display a large range of $2 n$ number, from 48 to 104 [79,96], in some cases also including polyploidization and interspecific hybridization events. In C. batrachus $(2 n=104)$, a surprising spread of the $5 S$ rDNA sequences over 27 chromosomal pairs occurs, directly linked with multiple centric fissions [79]. In addition, some other siluriform lineages experienced large karyotypic differentiation such as Callichthyidae, Loricariidae, and Trichomycteridae. In contrast, in families Amyblicipitidae, Ictaluridae, and Sisoridae, only few species possess a reduced $2 n$ number (reviewed in the work of [97]). However, it is evident that siluriform catfishes have, in general, much higher karyotypic diversity than their sister lineage Characiformes. With caution, in view of the fact that only about $15 \%$ of the siluriform fishes have been cytogenetically examined to date, it is noteworthy that the largest chromosomal diversity was observed for Siluridae.

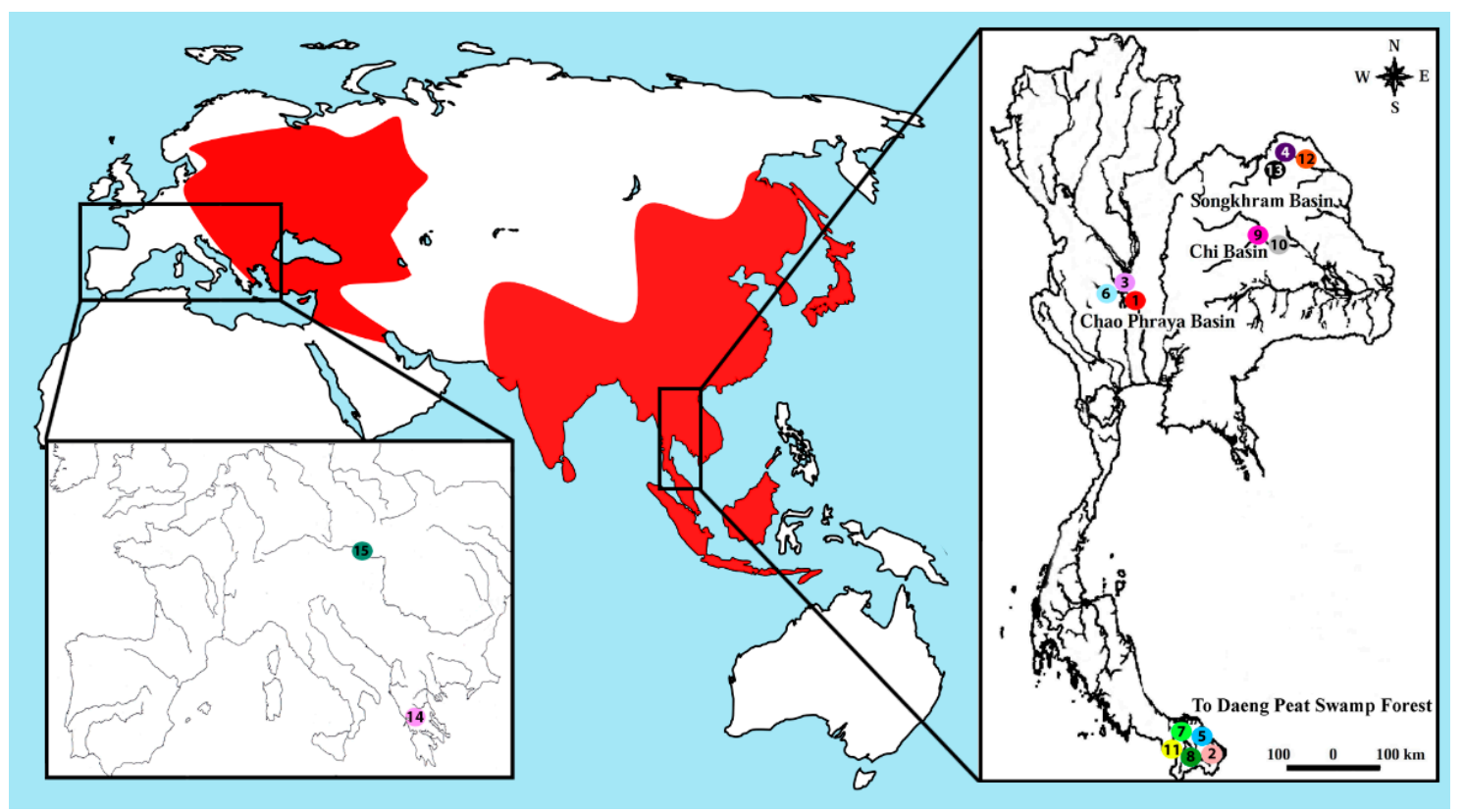

Figure 7. The current distribution of the fish family Siluridae (red color). Inset: Thailand map indicating the collection sites of the 13 species studied herein. 1. Belodontichthys truncates (red circle); 2. Kryptopterus bicirrhis (light pink circle); 3. Kryptopterus giminus (violet circle); 4. Kryptopterus limpok (purple circle); 5. Kryptopterus microcephalus (blue circle); 6. Micronema cheveyi (light blue circle); 7. Ompok fumidus (light green circle); 8. Ompok siluroides (green circle); 9. Phalacronotus apogon (pink circle); 10. Phalacronotus bleekeri (grey circle); 11. Silurichthys phaiosoma (yellow circle); 12. Wallago attu (orange circle); 13. Wallago micropogon (black circle); 14. Silurus aristotelis (pink circle); and 15. Silurus glanis (dark green circle). The maps were created using QGis 3.4.3, Inkscape 0.92 and Photoshop 7.0. 


\section{Materials and Methods}

\subsection{Individuals and Mitotic Chromosome Preparation}

Fifteen silurid species were collected from distinct natural ecosystems of Thailand and Europe (Figure 7). The numbers and sexes of the individuals are presented in Table 2. The specimens were deposited in the fish collections of the Cytogenetic Laboratory, Department of Biology, Faculty of Science (Khon Kaen University) and National Museum of Natural History, Paris (MNHN 1997-0481, MNHN 1996-1382). Mitotic chromosomes were obtained by the protocol described in the work of [98]. All the experiments followed ethical protocols, and anesthesia was conducted with clove oil prior to the sacrifice of the animals. The process was approved by the Animal Ethics Committee of Khon Kaen University based on the Ethics of Animal Experimentation of the National Research Council of Thailand AEKKU23/2558. Samples of S. glanis and S. aristotelis were obtained under state fisheries permits and research was conducted with approval from the University of Thessaloniki Ethics Committee.

Table 2. Collection sites for the analyzed species with the respective sample sizes.

\begin{tabular}{|c|c|c|}
\hline Species & Locality & No. of Individuals \\
\hline Belodontichthys truncatus & Chao Phraya Basin (Thailand) (site 1) & (04 \$; 04 ஓ) \\
\hline Kryptopterus bicirrhis & To Daeng peat swamp forest (Thailand) (site 2) & (07 \&; 08 ஓீ) \\
\hline Kryptopterus geminus & Chao Phraya Basin (Thailand) (site 3) & (08 \&; 11 ळ) \\
\hline Kryptopterus limpok & Songkhram Basin (Thailand) (site 4) & (07 \&; 10 ஓ) \\
\hline Kryptopterus macrocephalus & To Daeng peat swamp forest (Thailand) (site 5) & (06 \&; 06 ஓ) \\
\hline Micronema cheveyi & Chao Phraya Basin (Thailand) (site 6) & (09 \$; 10 ஓ) \\
\hline Ompok fumidus & To Daeng peat swamp forest (Thailand) (site 7) & (05 \&; 07 ஓ) \\
\hline Ompok siluroides & To Daeng peat swamp forest (Thailand) (site 8 ) & (04 \&; 05 ஓ) \\
\hline Phalacronotus apogon & Chi Basin (Thailand) (site 9) & (06 ९; 05 ஓా) \\
\hline Phalacronotus bleekeri & Chi Basin (Thailand) (site 10) & (07 \&; 04 ஓ) \\
\hline Silurichthys phaiosoma & To Daeng peat swamp forest (Thailand) (site 11) & (04 \$; 06 ஓ) \\
\hline Wallago attu & Songkhram Basin (Thailand) (site 12) & (03 \&; 04 ஓ) \\
\hline Wallago micropogon & Songkhram Basin (Thailand) (site 13) & (04 \&; 04 ஓ) \\
\hline Silurus aristotelis & Trichonida Lake (Greece) (site 14) & (03 \&; 05 ஓ) \\
\hline Silurus glanis & Dyje River, Danube basin (Czech republic) (site 15) & (08 \&; 06 ஓ) \\
\hline
\end{tabular}

Sites 1 to 15 correspond to the localization of each collection region shown in Figure 7.

\subsection{Fluorescence In Situ Hybridization (FISH)}

FISH was done under high-stringency conditions on metaphase chromosome spreads [99], with specific probes for $5 \mathrm{~S}$ and $18 \mathrm{~S}$ rDNA and telomeric sequences. The $5 \mathrm{~S}$ rDNA probe included the transcriptional segment of the 5S rRNA gene, with 120 base pairs (bp), and the 200-base pair non-transcribed spacer (NTS) [100]. The $18 \mathrm{~S}$ rDNA probe corresponded to a 1400 base-pair segment of the 18S rDNA gene [101]. Both rDNA probes were directly labeled with the Nick-translation Labeling Kit (Jena Bioscience, Jena, Germany) by the fluorescent labels Atto488 (18S rDNA) and Atto550 (5S rDNA), according to the manufacturer's manual. We applied both rDNA probes in all analyzed species, with the exception of S. aristotelis, where only $18 \mathrm{~S}$ rDNA mapping was performed.

In order to check the presence of ITS (interstitial telomeric sequences), telomeric (TTAGGG) $n$ sequences were mapped in the species with the lowest $2 n$ (S. phaiosoma) using the DAKO Telomere PNA FISH Kit/Cy3 (DAKO, Glostrup, Denmark). 


\subsection{Comparative Genome Hybridization (CGH)}

Total genomic DNA (gDNAs) of the K. geminus, K. limpok, P. apogon, P. bleekeri, W. attu, and $W$. micropogon were extracted from liver tissue by the standard phenol-chloroform-isoamyl alcohol method [102]. As substantial variation in both $2 n$ number and karyotype formula were observed among species of the genus Kryptopterus and Wallago, the gDNA of K. geminus was compared with that of K. limpok in metaphase chromosomes of K. geminus. Similarly, the gDNAs of W. attu and $W$. micropogon were hybridized in metaphase chromosomes of $W$. attu. For these purposes, gDNAs of K. geminus and W. attu were directly labeled with Atto550 using the Nick-translation Labeling Kit (Jena Bioscience, Jena, Germany), while the gDNAs of K. limpok and W. micropogon were labeled with Atto488. To block common genomic repetitive sequences, C0t-1 DNA (i.e., a fraction of genomic DNA enriched for highly and moderately repetitive sequences), prepared according to Zwick et al. [103], was used in all experiments. The final hybridization mixture for each experiment was composed of $500 \mathrm{ng}$ labeled DNA of each compared species, plus $15 \mu \mathrm{g}$ of male-derived C0t-1 DNA from the respective species and the hybridization buffer (50\% formamide, $2 \times$ SSC, $10 \%$ SDSC $10 \%$ dextran sulfate and Denhardt's solution, pH 7.0). The gDNA of Phalacronotus apogon (Atto488) was also compared with that of P. bleekeri (Atto550) against metaphase chromosomes of P. apogon. The CGH experiments were performed according to Symonová et al. [22].

\subsection{Cytogenetic Analyses}

At least 30 metaphase spreads per individual were analyzed to confirm the $2 n$, karyotype structure, and FISH results. Images were captured using an Axioplan II microscope (Carl Zeiss Jena GmbH, Germany) with CoolSNAP and the images were processed using Image Pro Plus 4.1 software (Media Cybernetics, Silver Spring, MD, USA). Chromosomes were classified as metacentric (m), submetacentric (sm), subtelocentric (st), or acrocentric (a), according to the arm length ratios [104].

\section{Conclusions}

Chromosomal characteristics, including the mapping of repetitive DNA sequences and CGH procedures, clarified the evolutionary dynamism among silurid species. In this sense, the known extensive diversification of their karyotypic macrostructure could be better characterized. Our data provide evidence for a direct correlation between the genomic repetitive content and the notable karyotypic divergence in silurids. Thus, it is likely that repetitive DNAs played a direct role in promoting the chromosomal differentiation and biodiversity within this fish family.

Supplementary Materials: The following are available online at http://www.mdpi.com/1422-0067/20/14/3545/s1, Figure S1: Metaphase plates of Silurichthys phaiosoma showing the location of telomeric (TTAGGG) ${ }_{n}$ repeats. Bar $=5 \mu \mathrm{m}$.

Author Contributions: Conceptualization, P.R., W.F.M., and M.d.B.C.; Data curation, E.H.; Formal analysis, S.D., L.A.C.B., A.T., C.O.-C., and M.d.B.C.; Funding acquisition, M.B.C.; Investigation, E.H., S.T., R.A., and M.d.B.C.; Methodology, S.D., E.H., W.F.M., C.T., S.T., P.P. and W.S.; Project administration, T.L., L.A.C.B., P.R., W.S., A.T. and M.d.B.C.; Software, S.D.; Validation, T.L., W.F.M., A.T., C.T., C.O.-C., S.T., P.P., and W.S.; Visualization, S.D., P.R., W.F.M., W.S., A.T., C.O.-C., S.T., P.P., W.S., and R.A.; Writing-original draft, T.L., S.D., L.A.C.B., P.R., W.F.M., W.S., A.T., P.P., W.S., R.A., and M.d.B.C.; Writing-review and editing, T.L., S.D., L.A.C.B., P.R., E.H., W.F.M., W.S., A.T., C.T., C.O.-C., S.T., P.P., W.S., R.A., and M.d.B.C.

Funding: This work was supported by the Thailand Research Fund (TRF) through the Royal Golden Jubilee (RGJ) Ph.D. Programme Grant No. PHD/0165/2559 and the office of the Higher Education Commission and the Thailand Research Fund (TRF) MRG6080020. MBC was supported by Conselho Nacional de Desenvolvimento Científico e Tecnológico (CNPq) (Proc. Nos. 401962/2016-4 and 302449/2018-3), Fundação de Amparo à Pesquisa do Estado de São Paulo (FAPESP) (Proc. Nos. 2018/22033-1), and CAPES/Alexander von Humboldt (Proc. No. 88881.136128/2017-01). P.R. was supported by the project EXCELLENCE CZ.02.1.01/0.0/0.0/15_003/0000460 OP RDE.

Acknowledgments: The authors are grateful for FAPESP, CNPQ, CAPES, and Alexander von Humboldt foundation for the support.

Conflicts of Interest: None of the authors have any conflicts of interest in the manuscript. 


\section{References}

1. Kottelat, M. The fishes of the inland waters of Southeast Asia: A catalogue and core bibliography of the fishes known to occur in freshwaters, mangroves and estuaries. Raffles Bull Zool. 2013, 27, 1-663.

2. Fricke, R.; Eschmeyer, W.; van der Laan, R. Eschmeyer's Catalog of Fishes: Genera, Species, References; California Academy of Sciences: San Francisco, CA, USA, 2019.

3. Bornbusch, A.H. Phylogenetic relationships within the Eurasian catfish family Siluridae (Pisces: Siluriformes), with comments on generic validities and biogeography. Zool. J. Linn. Soc. 1995, 115, 1-46. [CrossRef]

4. Kobayakawa, M. Systematic revision of the catfish genus Silurus, with description of a new species from Thailand and Burma. Jpn. J. Ichthyol. 1989, 36, 155-186. [CrossRef]

5. Kottelat, M.; Freyhof, J. Handbook of European Freshwater Fishes; Publications Kottelat: Berlin, Germany, 2007.

6. Bogutskaya, N.G.; Naseka, A.M.; Shedko, S.V.; Vasileva, E.D.; Chereschnev, I.A. The fishes of the Amur River: Updated check-list and zoogeography. Ichtyological Explor. Freshw. 2008, 19, 301-366.

7. Nelson, J.S.; Grande, T.C.; Wilson, M.V.H. Fishes of the World, 5th ed.; John Wiley \& Sons: Hoboken, NJ, USA, 2016.

8. Bornbusch, A.H. Monophyly of the catfish family Siluridae (Teleostei: Siluriformes), with a critique of previous hypotheses of the family's relationships. Zool. J. Linn. Soc. 1991, 101, 105-120. [CrossRef]

9. Hardman, M. The phylogenetic relationships among non-diplomystid catfishes as inferred from mitochondrial cytochrome $b$ sequences; the search for the ictalurid sister taxon (Otophysi: Siluriformes). Mol. Phylogenet. Evol. 2005, 37, 700-720. [CrossRef] [PubMed]

10. Mo, T. Anatomy, relationships and systematics of the Bagridae (Teleostei: Siluroidei) with a hypothesis of siluroid phylogeny. Theses Zool. 1991, 17, 1-216.

11. Pinna, M.C.C. Higher-level phylogeny of Siluriformes (Teleostei, Ostariophysi), with a new classification of the order. Ph.D. dissertation, City University of New York, New York, NY, USA, 1993.

12. Diogo, R. Higher-level phylogeny of Siluriformes: An overview. In Catfishes Science; Arratia, G., Kapoor, B.G., Eds.; Science Publishers: Enfield, UK, 2003; pp. 353-384.

13. Sullivan, J.P.; Lundberg, J.G.; Hardman, M. A phylogenetic analysis of the major groups of catfishes (Teleostei: Siluriformes) using rag1 and rag2 nuclear gene sequences. Mol. Phylogenet. Evol. 2006, 41, 636-662. [CrossRef]

14. Stone, R. The last of the Leviathans. Science 2007, 316, 1684-1688. [CrossRef]

15. Linhart, O.; Šĕtch, L.; Švarc, J.; Rodina, M.; Audebert, J.P.; Grecu, J.; Billard, R. The culture of the European catfish, Silurus glanis, in the Czech Republic and in France. Aquat. Living Resour. 2002, 15, 139-144. [CrossRef]

16. Saenjundaeng, P. Encyclopedia of Freshwater Fishes in Thailand; Klungnana Vitthaya Press: Khon Kaen, Thailand, 2014.

17. Chapman, F.A.; Fitz-Coy, S.A.; Thunberg, E.M.; Adams, C.M. United States of America trade in ornamental fish. J. World Aquac. Soc. 1997, 28, 1-10. [CrossRef]

18. Oliveira, C.; Almeida-Toledo, L.F.; Foresti, F. Karyotypic evolution in Neotropical fishes. In Fish Cytogenetics; Pisano, E., Ozouf-Costaz, C., Foresti, F., Kapoor, B.G., Eds.; Science Publishers: Enfield, UK, 2007; pp. 111-164.

19. Cioffi, M.B.; Bertollo, L.A.C. Chromosomal distribution and evolution of repetitive DNAs in fish. In Repetitive DNA; Garrido-Ramos, M.A., Ed.; Karger Publishers: Basel, Switzerland, 2012; Volume 7, pp. 197-221.

20. Cioffi, M.B.; Moreira-Filho, O.; Ráb, P.; Sember, A.; Molina, W.F.; Bertollo, L.A.C. Conventional cytogenetic approaches-useful and indispensable tools in discovering fish biodiversity. Curr. Genet. Med. Rep. 2018, 6, 176-186. [CrossRef]

21. Cioffi, M.B.; Bertollo, L.A.C.; Villa, M.A.; de Oliveira, E.A.; Tanomtong, A.; Yano, C.F.; Supiwong, W.; Chaveerach, A. Genomic organization of repetitive DNA elements and its implications for the chromosomal evolution of channid fishes (Actinopterygii, Perciformes). PLoS ONE 2015, 10, e0130199. [CrossRef] [PubMed]

22. Symonová, R.; Majtánová, Z.; Sember, A.; Staaks, G.B.O.; Bohlen, J.; Freyhof, J. Genome differentiation in a species pair of coregonine fishes: An extremely rapid speciation driven by stress-activated retrotransposons mediating extensive ribosomal DNA multiplications. BMC Evol. Biol. 2013, 13, 42-52. [CrossRef] [PubMed]

23. Moraes, R.L.R.; Bertollo, L.A.C.; Marinho, M.M.F.; Yano, C.F.; Hatanaka, T.; Barby, F.F.; Troy, W.P.; Cioffi, M.B. Evolutionary relationships and cytotaxonomy considerations in the genus Pyrrhulina (Characiformes, Lebiasinidae). Zebrafish 2017, 14, 536-546. [CrossRef] 
24. Sember, A.; Bertollo, L.A.C.; Ráb, P.; Yano, C.F.; Hatanaka, T.; de Oliveira, E.A.; Cioffi, M.B. Sex chromosome evolution and genomic divergence in the fish Hoplias malabaricus (Characiformes, Erythrinidae). Front. Genet. 2018, 9, 1-12. [CrossRef] [PubMed]

25. Barby, F.F.; Bertollo, L.A.C.; de Oliveira, E.A.; Yano, C.F.; Hatanaka, T.; Ráb, P.; Sember, A.; Ezaz, T.; Artoni, R.F.; Liehr, T.; et al. Emerging patterns of genome organization in Notopteridae species (Teleostei, Osteoglossiformes) as revealed by zoo-FISH and comparative genomic hybridization (CGH). Sci. Rep. 2019, 9, 1112. [CrossRef]

26. Verma, J.; Lakra, W.S.; Kushwaha, B.; Sirajuddin, M.; Nagpure, N.S.; Kumar, R. Characterization of two freshwater silurid catfish using conventional and molecular cytogenetic techniques. J. Genet. 2011, 90,319-322. [CrossRef]

27. Lee, H.Y.; Yu, C.H.; Jeon, S.K.; Lee, H.S. The karyotype analysis on 29 species of freshwater fish in Korea. Bull. Inst. Basic Sci. Inha Univ 1983, 79-86.

28. Donsakul, T. Chromosome study on three species of silurid fishes, Kryptopterus cryptopterus, K. bleekeri and Ompok bimaculatus, of Thailand. In Proceedings of the 18th Congress on Science and Technology of Thailand, Bangkok, Thailand, 1992; pp. 398-399.

29. Donsakul, T. A study of chromosome in freshwater shark (Wallago attu), helicopter catfish (W. leerii), twisted-jaw sheatfish (Belodontichthys dinema) and glass catfish (Kryptopterus bicirrhis) from Thailand. In Proceedings of the 34th Kasetsart University Annual Conference (Fishery Section), Bangkok, Thailand, 1996; pp. 367-377.

30. Simporn, B. Cytogenetic of Sheatfish (Family Siluridae) in Thailand. Ph.D Dissertation, Khon Kaen University, Khon Kaen, Thailand, 2015.

31. Hinegardner, R.; Rosen, D.E. Cellular DNA content and the evolution of teleostean fishes. Amer. Natur. 1972, 106, 621-644. [CrossRef]

32. Magtoon, W.; Donsakul, T. Karyotypes of Silurichthys phaiosoma, S. schneideri, Ompok fumidus and Kryptopterus macrocephalus (Family Siluridae) from Thailand. In Proceedings of the 35th Congress on Science and Technology of Thailand, Bangkok, Thailand, 2009; p. B0084.

33. Pinthong, K.; Supiwong, W.; Simporn, B.; Chooseangjaew, S.; Kakampuy, W.; Tanomtong, A. A First chromosomal and nucleolar organizer regions (NORs) Analyses of Chevey's sheetfish, Micronema cheveyi (Siluriformes, Siluridae). Cytologia (Tokyo) 2017, 82, 435-441. [CrossRef]

34. Rishi, K.K. Mitotic and meiotic chromosomes of a teleost, Callichrous bimaculatus (Bloch) with indications of male heterogamety. Cienc. Cult. 1976, 28, 1171-1173.

35. Khuda-Bukhsh, A.R. Cytogenetic analyses in eight species of teleostean fishes (Pisces): Karyotypes, multiple Ag-NORs, sex chromosomes. Res. Rev. BioSci. 2007, 1, 47-52.

36. Sharma, R. Chromosomal stuides on two endangered catfishes Ompok bimaculatus (Bloch) and Ompak pabda (Hamilton-Buchanan). Indian J. Anim. Sci. 2008.

37. Gomonteir, B.; Tanomtong, A.; Supiwong, W.; Sikhruadong, S.; Neeratanaphan, L.; Sanoamuang, L. Standardized karyotype and idiogram of two-spot glass catfish, Ompok bimaculatus (Siluriformes, Siluridae) in Thailand by conventional and Ag-NOR staining techniques. Cytologia (Tokyo). 2012, 77, 459-464. [CrossRef]

38. Das, R.K.; Kar, R.N. Somatic chromosome analysis of a siluroid fish, Rita chrysea Day. Caryologia 1977, 30, 247-253. [CrossRef]

39. Datta, S.; Rahman, M.M.; Haque, M.A. Chromosomal studies on Ompok pabda (Hamilton). Online J. Biol. Sci. 2003, 3, 460-465.

40. Khuda Bukhsh, A.R.; Chanda, T. Somatic chromosomes of three species of hill stream fishes from Assam. In Fish Genetics in India; Das, P., Jhingran, A.G., Eds.; Today Tomorrow's Printers and Publishers: New Delhi, India, 1989; pp. 69-73.

41. Supiwong, W.; Tanomtong, A.; Jumrusthanasan, S.; Khakhong, S.; Leelarasamee, K.; Sanoamuang, L. A First karyotype analysis and chromosomal characteristic of nucleolar organizer regions (NORs) of common sheathfish, Micronema apogon (Siluriformes, Siluridae) in Thailand. Cytologia (Tokyo). 2012, 77, 53-58. [CrossRef]

42. Iliadou, K.; Rackham, B.D. The chromosomes of a catfish Parasilurus aristotelis from Greece. Jpn. J. Ichthyol. 1990, 37, 144-148.

43. Rab, P.; Karakousis, Y.; Peios, C. Karyotype of Silurus aristotelis with reference to the cytotaxonomy of the genus Silurus (Piscus, Siluridae). Folia Zool. (Czech Republic) 1994, 43, 75-81. 
44. Nogusa, S. Chromosome studies in Pisces, II. On the chromosomes of Sillago sihama (Sillaginidae) and Parasilurus asotus (Siluridae). Jpn. J. Genet 1951, 26, 153-155. [CrossRef]

45. Muramoto, J. On the chromosomes of Parasilurus asotus (Linne). Chrom. Inf. Serv. 1969, 10, 18-19.

46. Fujioka, Y. A comparative study of the chromosomes in Japanese freshwater fishes I. A study of the somatic chromosome of common catfish Parasilurus asotus (Linne) and forktailed bullhead Paleobagrus nudiceps (Sauvage). Bull. Fac. Educ. Yamaguchi Univ. 1973, 23, 191-195.

47. Arai, R.; Katsuyama, I. A chromosome study on four species of Japanese catfishes (Pisces, Siluriformes). Bull. Nat. Sci. Museum 1974, 187-192.

48. Ojima, Y. Cellular DNA contents of fishes determined by flow cytometry. La Kromosomo II 1990, 57, 1871-1888.

49. Kim, D.S. Karyotypes of nine species of the Korean catfishes (Teleostomi: Siluriformes). Korean J. Genet. 1982, 4, 57-68.

50. Yunhan, H.; Tun, Z. Karyotypic study of two species of Chinese catfishes (Siluridae). J. Wuhan Univ. Nat. Sci. Ed. 1983, 3.

51. Yu, X.J.; Zhou, T.; Li, Y.C.; Li, K.; Zhou, M. Chromosomes of Chinese Freshwater Fishes; Science Press: Beijing, China, 1989.

52. Cui, J.X.; Ren, X.H.; Yu, Q.X. Nuclear DNA content variation in fishes. Cytologia. 1991, 56, 425-429.

53. Zhang, S.M. Nucleolar organizer regions in four species of fishes. Chromosom. Inf. Serv. 1992, 53, 6-8.

54. Li, Y.; Li, K.; Zhou, T. Cellular DNA content of fourteen species of freshwater fishes. Acta Genet. Sin. 1983, 10, 384-389.

55. Kim, D.S.; Kim, I.B.; Huh, H.T.; Park, I. Cytogenetic analysis of catfish, Silurus asotus (Teleostomi: Siluriformes). Ocean Polar Res. 1988, 10, 33-37.

56. Yin, H.B.; Sun, Z.W.; Pan, W. The karyotype study on triploid catfish (Silurus asotus). J. Fish. China 1996, 20, 178-182.

57. Meszáros, B.; Bozhko, S.; Marian, T.; Krasznai, Z. About karyotype of Silurus glanis. Halászat 1975, 21, $110-111$.

58. Krasznai, Z. Silurus glanis kariólogial és szerologiai vizsgálatának eredményei. Results of karyological and serological studies in catfish Silurus glanis. Halászat. 1978, 24, 2-4.

59. Ráb, P. Karyotype of European catfish Silurus glanis (Siluridae, Pisces), with remarks on cytogenetics of siluroid fishes. Folia Zool. 1981, 32, 271-286.

60. Sofradzija, A. Chromosomes of the species Silurus glanis L. 1758 (Siluridae, Pisces). Genetics 1982, 14, $103-110$.

61. Vujosevic, M.; Zivkovic, C.; Desanka, R.; Jurisic, S.; Cakic, P. The chromosomes of 9 fish species from Dunav basin in Yugoslavia. Ichthyologia 1983, 15, 29-40.

62. Vasilev, V.P. Evolutionary Karyology of Fishes; Nauka Publishers: Moscow, Russia, 1985.

63. Al-Sabti, K. Cytogenetic studies on five species of Pisces from Yugoslavia. Cytobios 1987, 49, 175-188.

64. Ráb, P.; Mayr, B.; Roth, P. Chromosome banding study of European catfish, Silurus glanis (Pisces, Siluridae). Genetica 1991, 83, 153-157.

65. Hu, G.; Sun, G.; Zhang, Y.; Gu, Q.; Li, G.; Tang, H.; Fan, L. Karyotype analyses of northern sheatfish (Silurus soldatovi). J. Dalian Fish. Coll. 2005, 20, 318-321.

66. Rishi, K.K.; Singh, J. Chromosomal analysis of the Indian silurid, Wallago attu (Schneider) (Family: Siluridae). Chrom Inf. Serv. 1983, 34, 10-11.

67. Sharma, O.P.; Tripathi, N.K. Somatic chromosome analysis of Wallago attu, a siluroid fish from Jammu (J \& K), India. Perspect. Cytol. Genet. 1984, 4, 437-439.

68. Oliveira, C.; Gosztonyi, A.E. A cytogenetic study of Diplomystes mesembrinus (Teleostei, Siluriformes, Diplomystidae) with a discussion of chromosome evolution in Siluriforms. Caryologia. 2000, 53, 31-37. [CrossRef]

69. Kappas, I.; Vittas, S.; Pantzartzi, C.N.; Drosopoulou, E.; Scouras, Z.G. A time-calibrated mitogenome phylogeny of catfish (Teleostei: Siluriformes). PLoS ONE 2016, 11, e0166988. [CrossRef] [PubMed]

70. White, M.J.D. Chain processes in chromosomal speciation. Syst. Zool. 1978, 27, 285-298. [CrossRef]

71. King, M. Species Evolution: The Role of Chromosome Change; Cambridge University Press: Cambridge, UK, 1995; ISBN 0521484545.

72. Potter, S.; Bragg, J.G.; Blom, M.P.K.; Deakin, J.E.; Kirkpatrick, M.; Eldridge, M.D.B.; Moritz, C. Chromosomal speciation in the genomics era: Disentangling phylogenetic evolution of rock-wallabies. Front. Genet. 2017, 8, 1-18. [CrossRef] [PubMed]

73. Biémont, C.; Vieira, C. Genetics: Junk DNA as an evolutionary force. Nature 2006, 443, 521-524. [CrossRef] 
74. Sochorová, J.; Garcia, S.; Gálvez, F.; Symonová, R.; Kovařík, A. Evolutionary trends in animal ribosomal DNA loci: Introduction to a new online database. Chromosoma 2018, 127, 141-150. [CrossRef]

75. Gornung, E. Twenty years of physical mapping of major ribosomal RNA genes across the teleosts: A review of research. Cytogenet. Genome Res. 2013, 141, 90-102. [CrossRef]

76. Rebordinos, L.; Cross, I.; Merlo, A. High evolutionary dynamism in 5S rDNA of fish: State of the art. Cytogenet Genome Res. 2013, 141, 103-113. [CrossRef]

77. Pereira, C.S.A.; Aboim, M.A.; Ráb, P.; Collares-Pereira, M.J. Introgressive hybridization as a promoter of genome reshuffling in natural homoploid fish hybrids (Cyprinidae, Leuciscinae). Heredity 2014, 112, 343-350. [CrossRef]

78. Sember, A.; Bohlen, J.; Šlechtová, V.; Altmanová, M.; Symonová, R.; Ráb, P. Karyotype differentiation in 19 species of river loach fishes (Nemacheilidae, Teleostei): Extensive variability associated with rDNA and heterochromatin distribution and its phylogenetic and ecological interpretation. BMC Evol. Biol. 2015, 15, 251-272. [CrossRef]

79. Maneechot, N.; Yano, C.F.; Bertollo, L.A.C.; Getlekha, N.; Molina, W.F.; Ditcharoen, S.; Tengjaroenkul, B.; Supiwong, W.; Tanomtong, A.; De Bello Cioffi, M. Genomic organization of repetitive DNAs highlights chromosomal evolution in the genus Clarias (Clariidae, Siluriformes). Mol. Cytogenet. 2016. [CrossRef]

80. Symonová, R.; Howell, W. Vertebrate genome evolution in the light of fish cytogenomics and rDNAomics. Genes 2018, 9, 96. [CrossRef]

81. Boron, A.; Porycka, K.; Ito, D.; Abe, S.; Kirtiklis, L. Comparative molecular cytogenetic analysis of three Leuciscus species (Pisces, Cyprinidae) using chromosome banding and FISH with rDNA. Genetica 2009, 135, 199. [CrossRef]

82. Cioffi, M.B.; Martins, C.; Bertollo, L.A. Chromosome spreading of associated transposable elements and ribosomal DNA in the fish Erythrinus erythrinus. Implications for genome change and karyoevolution in fish. BMC Evol. Biol. 2010, 10, 271-279. [CrossRef]

83. Raskina, O.; Belyayev, A.; Nevo, E. Activity of the En/Spm-like transposons in meiosis as a base for chromosome repatterning in a small, isolated, peripheral population of Aegilops speltoides Tausch. Chromosom. Res. 2004, 12, 153-161. [CrossRef]

84. Raskina, O.; Barber, J.C.; Nevo, E.; Belyayev, A. Repetitive DNA and chromosomal rearrangements: Speciation-related events in plant genomes. Cytogenet. Genome Res. 2008, 120, 351-357. [CrossRef]

85. Eickbush, T.H.; Eickbush, D.G. Finely orchestrated movements: Evolution of the ribosomal RNA genes. Genetics 2007, 175, 477-485. [CrossRef]

86. Glugoski, L.; Giuliano-Caetano, L.; Moreira-Filho, O.; Vicari, M.R.; Nogaroto, V. Co-located hAT transposable element and 5S rDNA in an interstitial telomeric sequence suggest the formation of Robertsonian fusion in armored catfish. Gene 2018, 650, 49-54. [CrossRef]

87. Slijepcevic, P. Telomeres and mechanisms of Robertsonian fusion. Chromosoma 1998, 107, 136-140. [CrossRef]

88. Ruiz-Herrera, A.; Nergadze, S.G.; Santagostino, M.; Giulotto, E. Telomeric repeats far from the ends: Mechanisms of origin and role in evolution. Cytogenet. Genome Res. 2008, 122, 219-228. [CrossRef]

89. Ocalewicz, K. Telomeres in fishes. Cytogenet. Genome Res. 2013, 141, 114-125. [CrossRef]

90. Charlesworth, B.; Snlegowski, P.; Stephan, W. The evolutionary dynamics of repetitive DNA in eukaryotes. Nature 1994, 371. [CrossRef]

91. López-Flores, I.; Garrido-Ramos, M.A. The repetitive DNA content of eukaryotic genomes. In Repetitive DNA.; Garrido-Ramos, M.A., Ed.; Karger Publishers: Basel, Switzerland, 2012; Volume 7, pp. 1-28.

92. Vicari, M.R.; Artoni, R.F.; Bertollo, L.A.C. Comparative cytogenetics of Hoplias malabaricus (Pisces, Erythrinidae). A population analysis in adjacent hydrographic basins. Genet. Mol. Biol. 2005, 28, 103-110. [CrossRef]

93. Da Rosa, R.; Laforga Vanzela, A.L.; Rubert, M.; Martins-Santos, I.C.; Giuliano-Caetano, L. Differentiation of Y chromosome in the $\mathrm{X} 1 \times 1 \mathrm{X} 2 \times 2 / \mathrm{X} 1 \times 2 \mathrm{Y}$ sex chromosome system of Hoplias malabaricus (Characiformes, Erythrinidae). Cytogenet. Genome Res. 2010, 127, 54-60. [CrossRef]

94. Cioffi, M.B.; Martins, C.; Bertollo, L.A.C. Comparative chromosome mapping of repetitive sequences. Implications for genomic evolution in the fish, Hoplias malabaricus. BMC Genet. 2009, 10, 34. 
95. De Oliveira, E.A.; Sember, A.; Bertollo, L.A.C.; Yano, C.F.; Ezaz, T.; Moreira-Filho, O.; Hatanaka, T.; Trifonov, V.; Liehr, T.; Al-Rikabi, A.B.H.; et al. Tracking the evolutionary pathway of sex chromosomes among fishes: Characterizing the unique XX/XY1Y2 system in Hoplias malabaricus (Teleostei, Characiformes). Chromosoma 2018, 127, 115-128. [CrossRef]

96. Eyo, J.E. Cytogenetic variations in Clarias species (Clariidae: Siluriformes) of the Anambra river using leucocytes culture tecniques. Anim. Res. Int. 2005, 2, 275-286.

97. Arai, R. Fish Karyotype A Check List; Springer Japan: Tokio, Japan, 2011.

98. Bertollo, L.A.C.; Cioffi, M.B.; Moreira-Filho, O. Direct chromosome preparation from freshwater teleost fishes. In Fish Cytogenetic Techniques (Chondrichthyans and Teleosts); Ozouf-Costaz, C., Pisano, E., Foresti, F., Almeida Toledo, L.F., Eds.; CRC Press: Boca Raton, FL, USA, 2015; pp. 21-26.

99. Yano, C.F.; Bertollo, L.A.C.; Cioffi, M.B. Fish-FISH: Molecular cytogenetics in fish species. In Fluorescence in Situ Hybridization (FISH)_Application Guide; Liehr, T., Ed.; Springer: Berlin, Germany, 2017; pp. $429-444$.

100. Pendás, A.M.; Móran, P.; Freije, J.P.; Garcia-Vásquez, E. Chromosomal location and nucleotide sequence of two tandem repeats of the Atlantic salmon 5S rDNA. Cytogenet. Cell. Genet. 1994, 67, 31-36. [CrossRef]

101. Cioffi, M.B.; Martins, C.; Centofante, L.; Jacobina, U.; Bertollo, L.A.C. Chromosomal variability among allopatric populations of Erythrinidae fish Hoplias malabaricus: Mapping of three classes of repetitive DNAs. Cytogenet. Genome Res. 2009, 125, 132-141. [CrossRef]

102. Sambrook, J.; Russell, D.W. Molecular Cloning: A Laboratory Manual; Cold Spring Harbor Laboratory Press: New York, NY, USA, 2001.

103. Zwick, M.S.; Hanson, R.E.; Mcknight, T.D.; Islam-Faridi, M.H.; Stelly, D.M.; Wing, R.A.; Price, H.J. A rapid procedure for the isolation of C 0 t-1 DNA from plants. Genome 1997, 40, 138-142. [CrossRef]

104. Levan, A.; Fredga, K.; Sandberg, A.A. Nomenclature for centromeric position on chromosomes. Hereditas 1964, 52, 201-220. [CrossRef]

(C) 2019 by the authors. Licensee MDPI, Basel, Switzerland. This article is an open access article distributed under the terms and conditions of the Creative Commons Attribution (CC BY) license (http://creativecommons.org/licenses/by/4.0/). 